\title{
A Study on the Culture and Arts Activities of Migrant Women in the COVID-19 Era and Satisfaction of Non-face-to-face Media
}

\author{
Sang-yun Jeong ${ }^{1}$, Cheul Choi ${ }^{2}$. \\ ${ }^{1}$ The Doctor's Course, Department of Culture, University Chosun, South Korea, Art8633@naver.com \\ ${ }^{2}$ The Doctor's Course, Department of Culture, University Chosun, South Korea, eltorechoi@ daum.net \\ Corresponding author: Sang-yun Jeong
}

\begin{abstract}
Korea has been in a long fight against the Corona Virus Infectious Disease (COVID) 19 since its first confirmed case in the middle of January 2020. The COVID-19, which was first reported in Wuhan, China in December 2019, has shaken the society, politics, economy, and culture. Its enormous effect divided our timeline into the pre-Corona (BC, Before Corona) and the After Corona (AC) eras. As of September 16, 2020, the virus infected a total of more than 29,42 million people worldwide and the numbers are still rising, posing a major threat to the lives of multicultural families, especially immigrants and refugees, who are in difficult conditions. Thus, this paper studies the satisfaction of migrant women on the non-face-to-face cultural environment in Korea. specifically among the migrant women and their satisfaction on the non-face-to-face media. The study encountered difficulties to expel the samples because of the social distancing protocols due to COVID-19. Nevertheless, the researchers gathered the responses by visiting a Multicultural Family Support Center. The results of showed that the type of non-face-to-face media and the satisfaction level of the migrant women varied based on their interests. Furthermore, the migrant women are not fully enjoying their cultural and leisure lives, yet, they are still satisfied with their social lives.
\end{abstract}

Keywords: Migrant Women, CoronaVirus -19, Post Corona, On-tact Cultural Life

\section{Introduction}

A long time ago, Aristotle called human a social animal. According to him, the greatness of man is that he knew the finiteness of the time given to him, and that he left a trace of survival as one of the ways to appease the regret of the time. Examples include handprints of the Shobe Cave, the Altamira Cave, and the Lascaux Cave[1], which were discovered in southern France in 1994.

We define this long human journey in the name of culture and art. Today's culture and art, created by human communication and communion, are a token of greatness and a sign of human beings manifesting as social animals.

However, in 2020, we succumbed to a microscopic virus that was barely visible even under a microscope. In March 2020, the World Health Organization declared the COVID-19 (hereinafter referred to as "pandemics").

It forced us, as social animals, to live and work within a certain radius, with social distance at the forefront. The COVID-19 affects not only the Koreans but also the foreigners.

There were work dismissals and unpaid leaves among employees. Airline flights were cut off so those

Received: October 18, 2020; 1st Review Result: December 5, 2020; 2nd Review Result: January 22, 2021 Accepted: February 26, 2021 
who wanted to return home cannot go back. Online classes for students are done remotely through telecommunication and technologies. Furthermore, the effects of this pandemic are more severe on cultural and artistic activities.

The cultural and artistic activities, which have been freely enjoyed, are undergoing major changes. Instead of using large and colorful concert halls or art galleries with warm lighting, the activities utilize a variety of digital technologies (e.g. watching online in TVs or mobile devices) for home use, which made the "un-tact" viewing culture a natural routine in the post-corona era.

This paper is aimed to examine the content and satisfaction of online cultural activities experienced by multicultural migrant women and discuss ways to actively cope with COVID-19 in the untapped era.

\section{A Study on the Cultural Activities of Migrant Women}

As the concept of cultural activities varies depending on the perspectives of scholars, the classification criteria and methods differ depending on the characteristics of each activity. The scope consists of a number of programs, including participation in various arts activities, learning programs for culture, watching and creating movies, concerts, hobby activities, and participating in festivals and events, including various gatherings[2]. The following table describes the culture nostalgia of migrants surveyed by the Ministry of Culture, 2010 Sports and Tourism

[Table 1] 2010 Report on the Current Status of Migrant Culture (Reorganization of Researcher) Source: Ministry of Culture, Sports and Tourism website

\begin{tabular}{|l|l|c|c|}
\hline \multicolumn{2}{|c|}{} & In 2010 & 2008 (A full-length career) \\
\hline \multirow{4}{*}{ Watch an art event } & All & $50.1 \%$ & $48.2 \%$ \\
\cline { 2 - 4 } & Movies & $37.4 \%$ & $38.6 \%$ \\
\cline { 2 - 4 } & Performing arts & $21.6 \%$ & $7.2 \%$ \\
\cline { 2 - 4 } & Popular art & $16.9 \%$ & $4.4 \%$ \\
\cline { 2 - 4 } & An art exhibition & $9.3 \%$ & $3.5 \%$ \\
\hline \multirow{5}{*}{$\begin{array}{c}\text { Cultural education } \\
\text { activities }\end{array}$} & All & $32.1 \%$ & $9.1 \%$ \\
\cline { 2 - 4 } & Living culture & $20.0 \%$ & $5.5 \%$ \\
\cline { 2 - 4 } & Hobby & $14.8 \%$ & $1.3 \%$ \\
\cline { 2 - 4 } & Culture and arts & $12.5 \%$ & $1.1 \%$ \\
\cline { 2 - 4 } & Korean history & $8.0 \%$ & $2.1 \%$ \\
\cline { 2 - 4 } & Native culture and art & $5.4 \%$ & $\ldots$ \\
\hline
\end{tabular}

It was confirmed that the cultural nostalgia of immigrants increased significantly in 2010 compared to 2008. The number of visitors on performaing arts increased from 7.2 percent to 21.6 percent, public art from 4.4 percent to 16.9 percent, art exhibitions increased from 3.5 percent to 9.3 percent, and cultural and educational activities from 9.1 percent to 32.1 percent.

The following are prior studies on cultural activities of migrant women. First, it is about family unit cultural activities. According to the survey conducted by the Healthy Family Support Center under the Korea Health and Family Promotion Agency, most of the families were participating in various programs, including performances, exhibitions, cultural experiences and festival events conducted by related agencies. This has created a positive effect on increasing family intimacy and strengthening ties to each other. However, it was exposed to the lack of one-sided management methods led by the government, flexibility in the process of proceeding, and two-way communication[3].

Second, it is a culture and arts group education program for migrant women. Depending on the type, 
the program will be divided into programs for experiencing Korean culture, programs for relieving the nostalgia of migrants, and programs for understanding mutual culture. The content ranged from selfhelp gatherings enjoyed by people with similar hobbies to clubs with a certain format[4].

Third, it is a study of individual or small-scale cultural and artistic activities. It was having a big impact on self-development and creating positive energy in life. Active cultural activities through individual and small-scale gatherings also produced positive results, including the formation of interpersonal relationships.

In particular, activities supported in terms of cultural diversity were mainly hobbies for selfdevelopment, including performances, singing, and dancing. However, there were some cases in which it was difficult to maintain continuity due to the economic conditions of the participants and the idleness of the home environment[5].

[Table 2] Types of Cultural Activities of Migrant Women (Arbitrary Composition of Researcher)

\begin{tabular}{|c|c|c|c|}
\hline Sortation & Type & Content & Others \\
\hline $\begin{array}{c}\text { Family } \\
\text { Program }\end{array}$ & $\begin{array}{c}\text { Cooking class, Korean culture experience, } \\
\text { multi-cultural family festival }\end{array}$ & $\begin{array}{c}\text { Performance, exhibition, } \\
\text { cultural experience, festival } \\
\text { events }\end{array}$ & $\begin{array}{c}\text { Related } \\
\text { agency }\end{array}$ \\
\hline $\begin{array}{c}\text { Group } \\
\text { Program }\end{array}$ & $\begin{array}{c}\text { Korean culture experience, nostalgia, mutual } \\
\text { understanding program }\end{array}$ & Watch, visit, experience & $\begin{array}{c}\text { Group } \\
\text { activities }\end{array}$ \\
\hline $\begin{array}{c}\text { Individual } \\
\text { Program }\end{array}$ & Active cultural activities & Performing & $\begin{array}{c}\text { Individual and } \\
\text { Small Unit } \\
\text { Meetings }\end{array}$ \\
\hline
\end{tabular}

The premise of the preceding studies on cultural activities discussed above was that in modern society, cultural activities have a productive meaning of recharging, including relaxation and creating creative values for the future.

These migrant women's cultural activities were before COVID-19. In other words, the majority of the programs were conducted through face-to-face, and the scope of their activities and movements were extensive. While personal hobbies and small groups were held in limited spaces, most of them were held in public cultural complexes or open spaces by genre.

However, cultural activities of migrant women in the post-corona era are also affecting their quality of life as their scope is narrowing and opportunities are reduced. Cultural activities are not a matter of the past, but a basic value of human life and a criterion for determining the quality of life.

\section{Theoretical Consideration}

\subsection{Understanding COVID-19}

In December 2019, an unknown virus began in Wuhan, China. The virus has been named severe acid virus syndrome coronavirus 2 (SARS-CoV-2). Later, the World Health World Health Organization has named the disease as Corona Virus Infectious Disease-19 (COVID-19), which means the disease caused by the coronavirus virus in 2019 .

After an unknown source of pneumonia in Wuhan was identified as a novel coronavirus in December, within thee months the outbreak occured, spreading the infection to about 114 countries where more than 4,000 people died. Thus, on March 11, 2020, the World Health Organization declared that COVID19 a global pandemic (Park Soo-eun, 2020).COVID-19 is transmitted when an infected person coughs and sneezes, the viruses and are mixed in the nasal passages such as saliva, infiltrating other people's respiratory systems through the eyes, nose, and mucous membranes. 
The virus commonly known to have a travel distance of 2 meters. Common symptoms include fever (37.5 degrees) after a certain period of incubation, coughing, difficulty of breathing, nausea, diarrhea, stomachache, and pneumonia. There are also cases of muscle pain and fatigue, and rare cases of asymptotic infections[6].

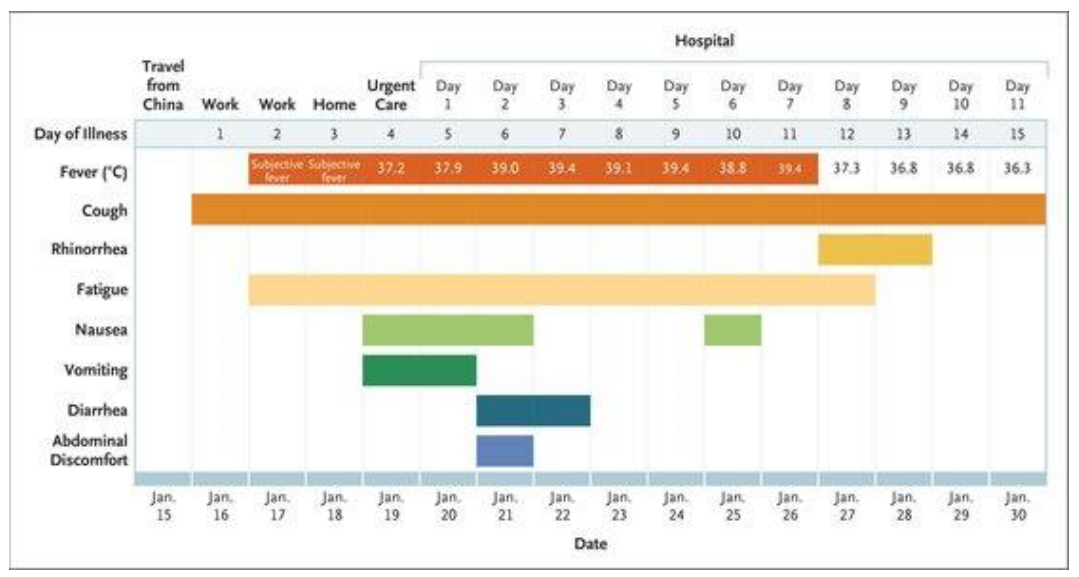

[Fig. 1] A Graph of the Symptoms of the First Confirmed Patient in the United States in the Early Stages of COVID-19 Source: JoongAng Ilbo 2020.03.12

COVID-19 has a lower fatality rate compared to MERS and SARS, but with much higher transmission and speed. The biggest feature of all is that there are asymptomatic infections that are not visible in MERS and SARS. In addition, 239 scientists from 32 countries around the world have raised the possibility of air transmission of COVID-19, prompting a series of reports that they have sent an open letter to the WHO urging the improvement of preventive measures.

Nowadays the day begins with the announcement of the number of COVID-19 confirmed cases. The cumulative number of COVID-19 confirmed worldwide surpassed 29.42 million on September 16, 2020. Given the current pace of increase in the number of confirmed cases, it is self-evident that the number exceeds 30 million in a day or two.

The death toll is also expected to reach 1 million in the near future. In particular, the United States has 6,602,981 confirmed COVID-19 ca.ses with 15,693 confirmed deaths, India with 4,930,236 confirmed cases and 80,776 deaths, Brazil with 4,382,263 confirmed cases and 133,119 deaths, and Russia with 1,073,849 confirmed cases and 18,785 deaths[7].

\section{$29,429,872$ Confirmed cases on the 16th / 931,948 people died}

\begin{tabular}{c|c|c|r|r|r|r|r}
\multicolumn{1}{c}{ As of September 16, $2020,09: 00$} \\
\hline Country/day & \multicolumn{1}{c|}{9.10} & 9.11 & 9.12 & 9.13 & 9.14 & 9.15 & \multicolumn{1}{c}{9.16} \\
\hline USA & $6,358,247$ & $6,395,603$ & $6,438,739$ & $6,479,157$ & $6,516,861$ & $6,551,575$ & $6,602,981$ \\
\hline India & $4,370,128$ & $4,465,863$ & $4,562,414$ & $4,6599,84$ & $4,754,356$ & $4,846,427$ & $4,930,236$ \\
\hline Brazil & $4,197,889$ & $4,238,446$ & $4,282,164$ & $4,315,687$ & $4,330,455$ & $4,345,610$ & $4,382,263$ \\
\hline Russia & $1,042,007$ & $1,046,370$ & $1,051,874$ & $1,057,362$ & $1,062,811$ & $1,068,320$ & $1,073,849$ \\
\hline Peru & 696,190 & 702,776 & 710,067 & 716,670 & 722,832 & 722,832 & 7296,19 \\
\hline Columbia & 671,848 & 679,513 & 686,851 & 694,664 & 702,088 & 708,964 & 716,319 \\
\hline Mexico & 647,507 & 652,364 & 658,299 & 663,973 & 688,381 & 671,716 & 676,487 \\
\hline South africa & 640,441 & 642,431 & 644,438 & 646,398 & 648,214 & 649,793 & 659,749 \\
\hline Spain & 543,379 & 554,143 & 566,326 & 566,326 & 566,326 & 593,730 & 603,167 \\
\hline Argentina & 488,007 & 500,034 & 512,293 & 524,198 & 5357,05 & 546,481 & 555,537 \\
\hline
\end{tabular}

[Fig. 2] COVID-19 Infection Status in Major Developing Countries (Source: Digital Chosun Ilbo) 
Now is a very important time to prepare for the post-corona era, This pandemic demands a new sight life to mankind. The so-called "New Normal"will promote the digital society through the acceleration of "un-tact business" and online services, especially in the fields of smart healthcare industry and culture and arts industries. The services will particularly use digital based online distribution, digital content, $\mathrm{AR}$ and VR, edu-tech, and video conferencing applications[8].

\subsection{On-tact Digital Cultural Life}

Digital cultural life literally refers to an era in which digital life is centered on media. The rapid development of digital media today has changed people's daily lives by a large margin. Digital technologies have made it possible for various media such as images, sounds, and text to interact closely with each other. As a result, expanded media culture not only enables a synesthetic experience that stimulates five senses, but also opens a new stage for promoting public participation.

Words that go beyond the analog methods of TV and radio to refer to modern times as "the age of smartphones and tablets" or "the era of TGiF" prove this. TGiF refers to the social network services (SNS) such as Twitter, Google, iPhone, and Facebook [9]. Digital content digitally produces, processes, and distributes text, audio, image, video, and games.

Such rapidly diversifying digital media is creating a new paradigm that transcends genres and crosses boundaries through convergence between media. What is drawing attention here is the open network culture society.

It means a society in which continuous intercommunication is possible without physical constraints of time and space. As cultural and artistic programs such as literature, music, and art become more colorful in the face of rapidly changing multi-media and multi-cultural situations due to weakened boundaries and increased exchanges among network participants, it is settled in the form of new cultural life in the crisis such as post-corona and the era as shown in the following picture[10].

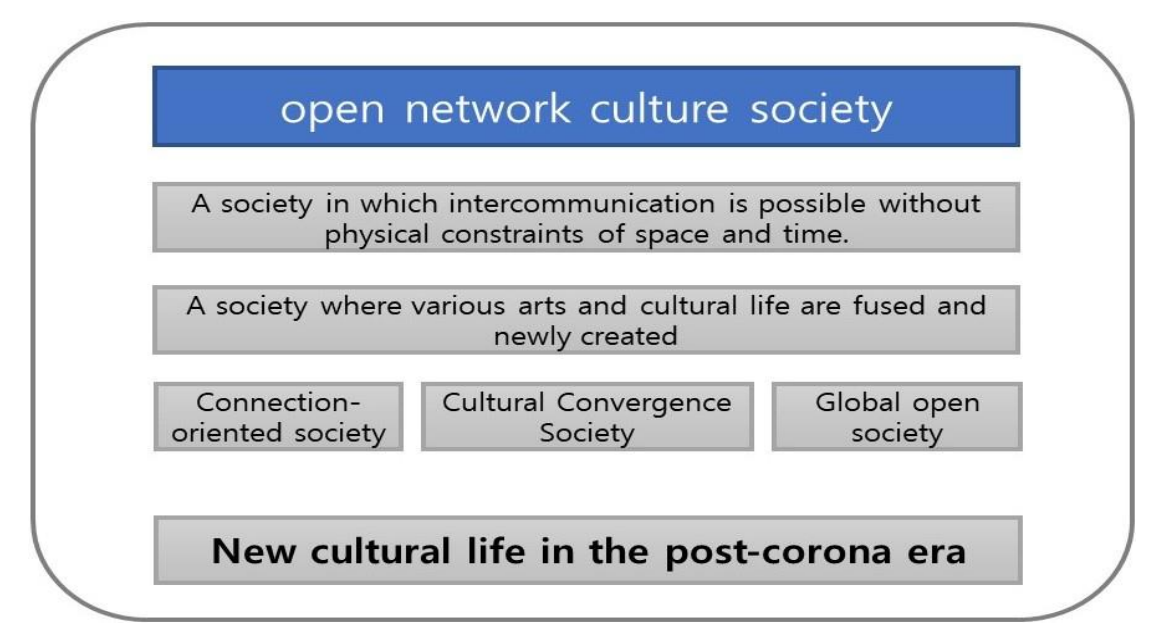

[Fig. 3] Open Network Definition of Culture Society (Management Re-editing)

The post-corona era replaces the offline cultural life enjoyed so far, seeking cultural activities through un-tact, which consumes culture through broadcasting and online, and creating a variety of cultural contents aimed at it. Now, it can be said that the era of "untact + on," a culture that seeks to connect with the outside world via online, or LAN, has arrived.

The prolonged social distance to prevent the spread of COVID-19 has led to the cancellation of various cultural events and the closure of cultural complexes, including concert halls, art galleries and cultural complexes,". 
There are many characteristics of the digital age, such as the speed, accuracy, and multimedia of information, but the most important thing is that it is possible to reproduce, transform, and transmit information indefinitely.

Cultural contents are also changing into contents that can be used in a variety of ways in line with the digital era. These days, cell phones are not just a means of communication, such as phone calls and text messages, but also a multimedia device for broadcasting and movies, music, games, photos and videos.

This post-corona era is due to the terrifying infectious power of the COVID-19, which allows anyone to enjoy a cultural life even if they do not go outside.

The COVID-19 crisis, coupled with the full-fledged advent of the fourth industrial revolution, including AI, AR, IT, and digital contents, is gaining momentum in the observation that non-face-toface cultural life will emerge as a key issue

\subsection{Migrant Women and Digital Cultural Life}

Since the middle of 2000s, Korean society has seen a rapid increase in the number of immigrants in terms of size and diversity. Recently, the number of foreigners staying for various purposes such as labor and studying abroad has increased, and the forms of foreigners residing in Korea, including marriage immigrants and children from multicultural families, have also diversified, highlighting racial, ethnic and cultural pluralism[11].

People, products, finance, and information, which used to mainly move in limited space, are now having a huge impact on social structure and cultural order in various ways and forms across the border based on the innovation of the fourth industrial revolution, including telecommunications and transportation, and are reorganizing the trend.

According to the Korean Language Institute, "migration" means that groups such as individuals and ethnic groups leave their original areas and move to other regions to settle down, while "migrant women" are collectively referred to foreign women living in Korea through international marriages, foreign workers staying in Korea for employment, and international students residing in Korea for educational purposes.

According to the Immigration Policy Headquarters, the number of registered foreigners increased from 1,091,531 in 2014 to 1,171,765 in 2017, and by the end of February 2020, the number of registered foreigners will reach $1,279,412[12]$.

[Table 3] Status of Registered Foreigners and the Trend of Increase and Decrease by Year. Source: Immigration and Foreign Policy Headquarters (2020.02.29. present, Unit : num)

\begin{tabular}{|c|c|c|c|c|c|c|c|}
\hline Sortation & 2014 & 2015 & 2016 & 2017 & 2018 & 2019 & Feb, 2020 \\
\hline $\begin{array}{c}\text { Number of } \\
\text { people }\end{array}$ & $1,091,531$ & $1,143,087$ & $1,161,677$ & $1,171,765$ & $1,246,626$ & $1,271,807$ & $\mathbf{1 , 2 7 9 , 4 1 2}$ \\
\hline $\begin{array}{c}\text { Year-on- } \\
\text { year } \\
\text { rate of } \\
\text { increase } \\
\text { and } \\
\text { decrease }\end{array}$ & $10.7 \%$ & $4.7 \%$ & $1.6 \%$ & $0.9 \%$ & $6.4 \%$ & $2.0 \%$ & $0.6 \%$ \\
\hline
\end{tabular}

Migrants in Korea is more than 2.5 percent of the population, the standard for multicultural countries proposed by the UN. The UNESCO and OECD already defined Korea as an immigrant country.

The Korean society, which is valued by the single ethnic group and lineage, is being transformed into a new multicultural society due to the rapid influx of foreign workers and marriage immigrants[13].

Now, we need to recognize multiculturalism and find alternatives to live in a harmonious multi-racial 
and multi-ethnic era, a multiculturalism that guides us beyond the national anthem and toward a better life and direction. This concept is a public symbol system available to anyone.

Multiculturalism does not only mean tolerance of cultural diversity, but also means that a society is transformed into a multicultural society, and social institutions and structures should shape multiculturalism policies.

However, the initial process of coping with COVID-19 lacked the universality and inclusiveness of policy from the perspective of a multicultural society, and there were trials and errors in administration.

The policy exclusion and discrimination suffered by immigrant families, including refugees and migrant workers, have emerged in various fields, starting with the purchase of public masks.

There was no multilingual guide to COVID-19 related prevention methods, treatment costs for foreign infected persons, postponement of school opening, and online learning, especially there was no alternative to their cultural activities.

Viruses do not discriminate between locals and foreigners. In this crisis, it was forced to rely on digital media as one of the ways to find comfort and rest, both directly and indirectly.

The post-corona era is changing the landscape of life around online due to space constraints. In watching movies, the facial expressions of the actors, which were not seen in colorful and large theaters and concert halls, can now be seen close-up through the digital devices. This is also true for the famous works in art museum.

\section{Research Method}

\subsection{Subjects and Contents of Research}

[Table 4] General Characteristics of Research Subjects. Arbitrary Composition of Researchers.

\begin{tabular}{|c|c|c|c|c|c|c|c|}
\hline Sortation & Contents & $\begin{array}{l}\text { Number } \\
\text { of } \\
\operatorname{cases}(\mathrm{N})\end{array}$ & $\begin{array}{c}\text { Percentage } \\
(\%)\end{array}$ & Sortation & Contents & $\begin{array}{l}\text { Number } \\
\text { of } \\
\operatorname{cases}(\mathrm{N})\end{array}$ & $\begin{array}{c}\text { Percentage } \\
(\%)\end{array}$ \\
\hline \multirow{4}{*}{ Age } & 20 's & 8 & 26 & \multirow{4}{*}{ School } & $\begin{array}{l}\text { Graduated } \\
\text { high school }\end{array}$ & 13 & 43 \\
\hline & 30 's & 11 & 36 & & Diploma & 8 & 27 \\
\hline & 40 's & 7 & 24 & & Bachelor & 72 & 23 \\
\hline & 50 's & 4 & 14 & & $\begin{array}{l}\text { Master's } \\
\text { degree }\end{array}$ & 7 & 7 \\
\hline \multirow{4}{*}{ Nationality } & China & 17 & 57 & \multirow{8}{*}{ Occupation } & Students & 3 & 10 \\
\hline & Philippines & 5 & 17 & & Office worker & 7 & 23 \\
\hline & Pakistan & 1 & 3 & & House work & 6 & 20 \\
\hline & Vietnam & 7 & 23 & & $\begin{array}{l}\text { professional } \\
\text { occupation }\end{array}$ & 3 & 10 \\
\hline \multirow{4}{*}{ Address } & $\begin{array}{c}\text { Gwang-san } \\
\text { district }\end{array}$ & 16 & 53 & & $\begin{array}{c}\text { Self- } \\
\text { employment }\end{array}$ & 1 & 3 \\
\hline & West district & 5 & 17 & & Services & 4 & 13 \\
\hline & $\begin{array}{l}\text { North } \\
\text { district }\end{array}$ & 6 & 20 & & $\begin{array}{l}\text { A public } \\
\text { officer }\end{array}$ & 4 & 14 \\
\hline & $\begin{array}{l}\text { South } \\
\text { district }\end{array}$ & 3 & 10 & & Others & 2 & 7 \\
\hline
\end{tabular}

The study was conducted from September 8 to 18,2020 on migrant women at three ulti-cultural Family Support Centers located in Gwang-ju. A total of 35 copies were collected during the survey 
process and 30 of them were finally selected and analyzed.

The number of samples was small because of the difficulty in sampling through face-to-face and the social distancing protocols In this study, a survey was conducted with three questions[14].

First, the satisfaction level on cultural and artistic performances in concert hall or on-site viewing using un-tact for the past nine months of COVID-19 (January 1 to September 2020).

Second, the satisfaction level of un-tact media used to enjoy culture or art in the COVID-19 situation was understood.

Finally, we have identified the feelings of the subject's life for the past nine months in the post-corona situation.

\subsection{The Result of the Study}

\subsubsection{Survey on Non-face-to-face Media Utilization Experience}

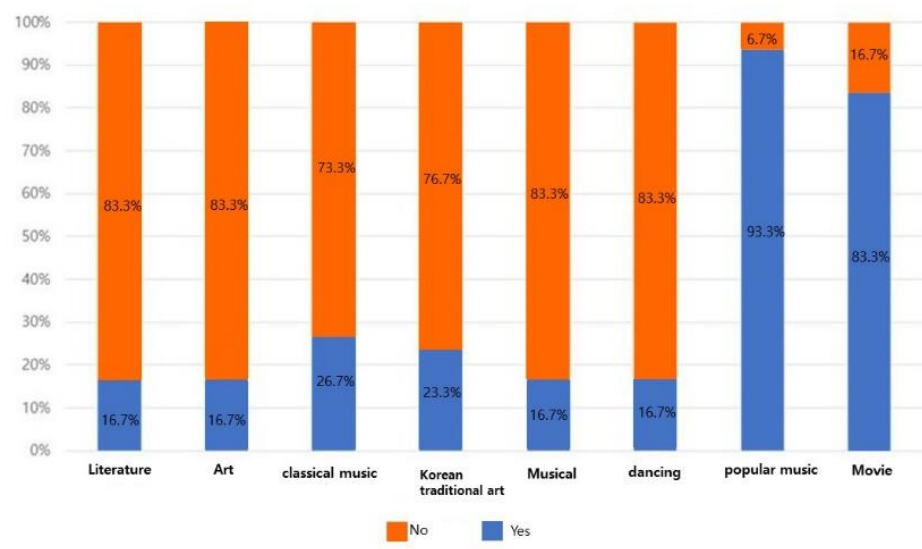

[Fig. 4] Questions on Culture and Arts Enjoyed using Non-face-to-face Media

The table above shows the experience of cultural and artistic activities through non-face-to-face media (un-tact). They participated in cultural activities in most areas including literature (16.7\%), pop music (93.3\%), movies (83.3\%), and Western music (26.7\%).

However, musicals (16.7\%) and dances (16.7\%) that should be watched in unpopular events, large theaters, or concert halls were found to have a relatively low participation rate. The following are the results of the survey on the satisfaction viewing using non-face-to-face media and on performance halls after COVID-19.

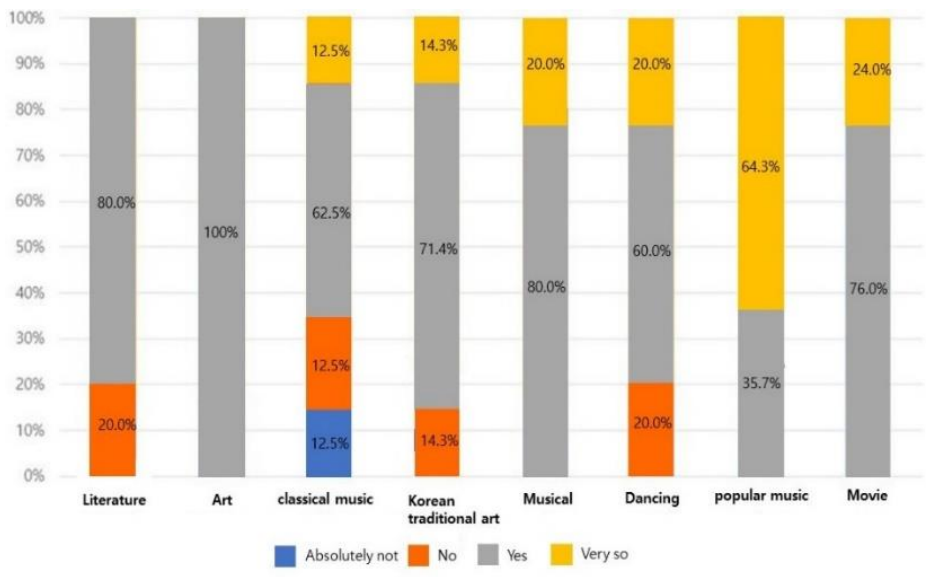

[Fig. 5] Relative Satisfaction Survey between Performance Venues and Non-face-to-face Media 
Cultural activities that participated in non-face-to-face media including popular music, movies, musicals, and art were highly satisfied by the migrant women. Both satisfaction and dissatisfaction relatively exist in viewing cultural activities of the literary field, dance, and traditional Korean art. The Western music was found to be very unsatisfactory to be watched in non-face-to-face media.

\subsubsection{Satisfaction Survey of Un-tact Media}

During the COVID-19 situation, $66.6 \%$ of the respondents said they were satisfied with the performance, and $90 \%$ said they were comforted as much as they were watching the performance in person-to-person performances. In addition, $67 \%$ of the respondents were impressed enough.

Forty-six percent of the respondents were willing to pay for the use of non-face-to-face media to enjoy culture and arts.

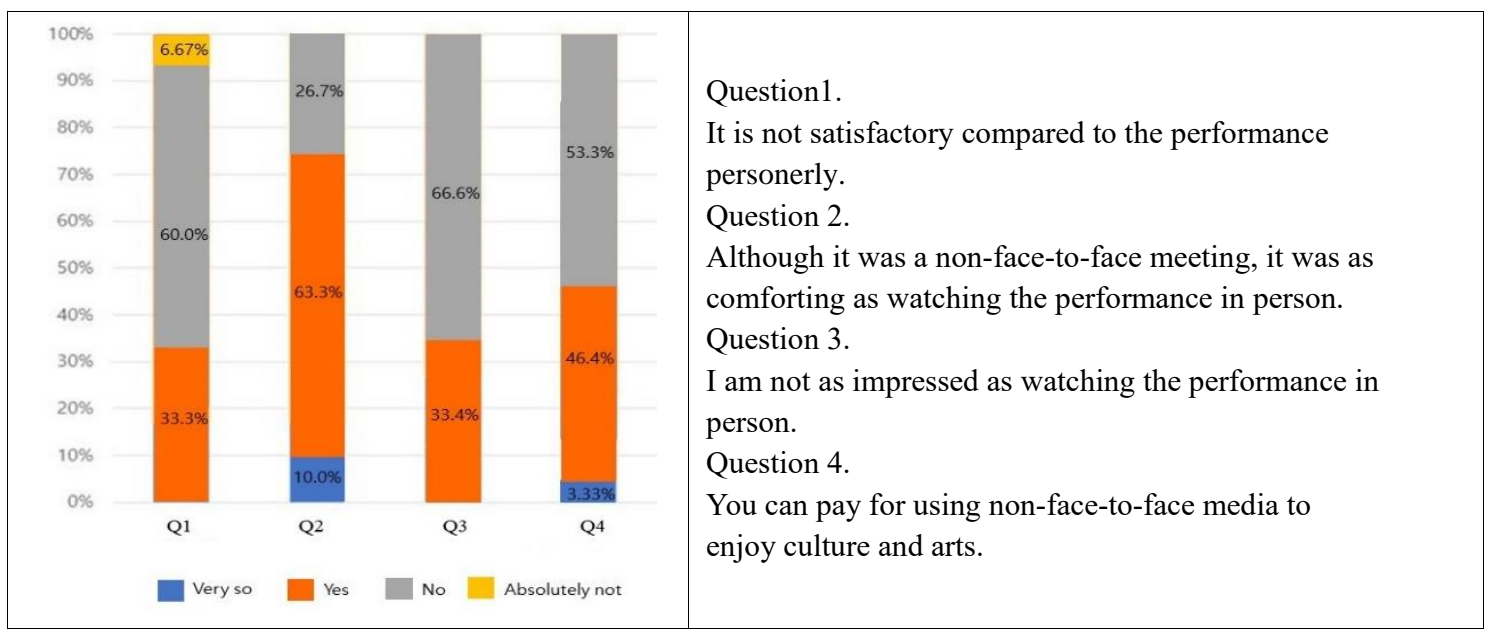

[Fig. 6] Satisfaction Survey of Non-face-to-face Media

\subsubsection{Changes in Living Conditions After COVID-19}

According to the survey on the effects of COVID-19 on living satisfaction, the migrant women are satisfied with the current social life (63\%), they are dissatisfied with the leisure activities $(63.4 \%)$, dissatisfied with how to spend weekends or evenings (73.3\%), and dissatisfied with how to spend time on weekends or evenings (56.7\%). While 86.7 percent thought they were worthy, only 56.7 percent said they were satisfied with themselves.

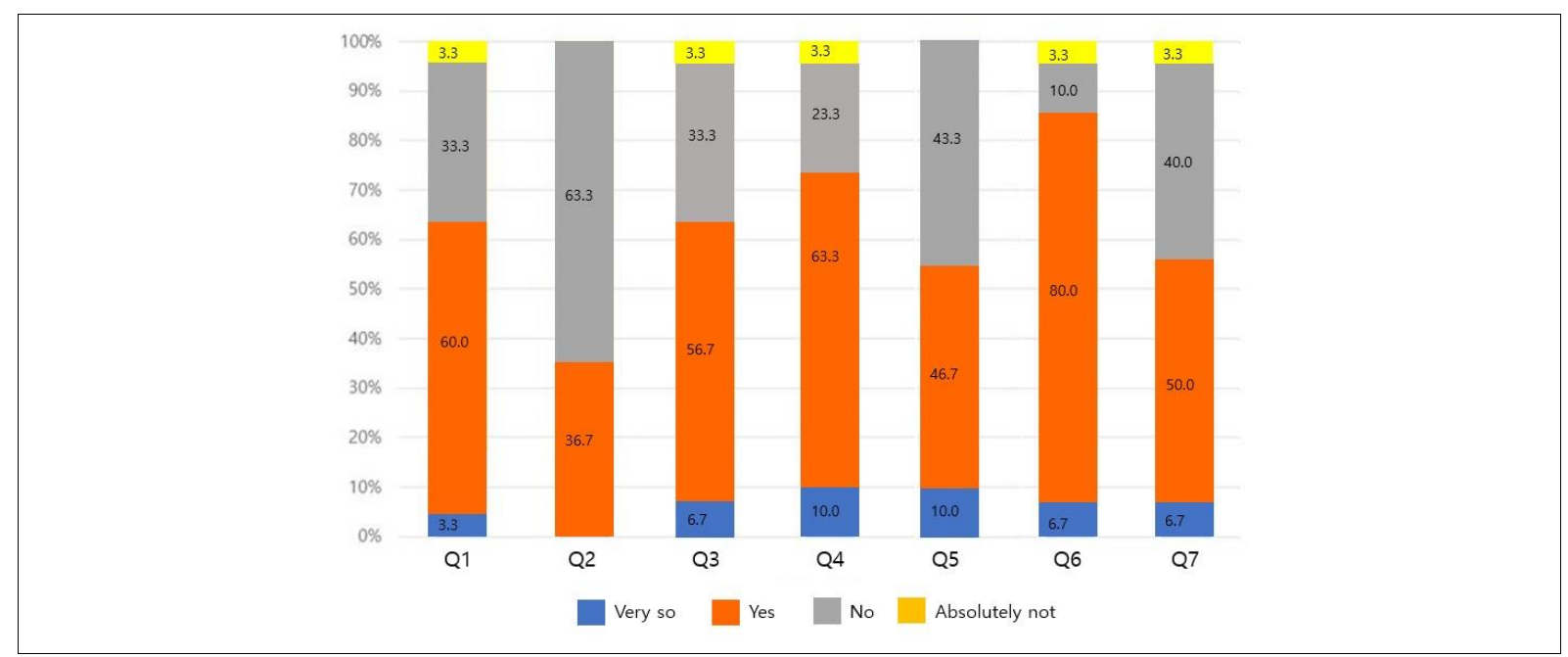


Question 1. I am satisfied with my current social life.

Question 2. I am satisfied with the way I spend my day these days.

Question 3. I am dissatisfied with my leisure activities these days.

Question 4. I am not satisfied with how to spend the evening or weekend these days.

Question 5. I don't have as much freedom as I want.

Question 6. I feel like I'm a worthy person.

Question 7. I am generally satisfied with myself.

[Fig. 7] Satisfaction Survey for Overall Life

\section{Conclusion and Suggestions}

The environment in which people from diverse cultural backgrounds enjoy living culture in everyday areas regardless of ideology and nationality has been created under un-tact. This new type of cultural activity raises the issue of various cultural adaptations.

Most migrant women have difficulty enjoying culture due to the lack of cultural facilities and the surrounding environment, including economic conditions. Most people are in a hurry to adapt to Korean society rather than quality of life and self-development.

To support the cultural adaptation of migrant women, the government provides cultural services using various media, but migrant women are still having difficulty adjusting to life in Korea due to cultural and linguistic difference.

It is also true that their children are also suffering from identity, language confusion and social prejudice. Therefore, through the recent un-tact cultural activities, we hope to design a positive development direction for cultural adaptation and create synergy for communication.

This calls for new forms of cultural participation not only for ordinary citizens but also for multicultural migrant women, and the government will have to consider various policy management to ease cultural adaptation of multicultural migrant women.

The general policy management process for supporting multicultural migrant women is easy to be limited to macro- and direct economic support measures, and what should be discussed as important as the process is the diversity of micro-policy sectors and programs of cultural activities occurring in everyday cities and spaces so that migrant women can enjoy various leisure activities for successful cultural adaptation for this purpose[15].

First, it is necessary to recognize migrant women as Koreans and distribute family cultural activities programs.

Second, it is not one-sided information delivery, but the development of programs with culture and arts that can induce interest and participation and stimulate curiosity.

Third, the development of current affairs and culture programs intended to adapt quickly to Korean culture and the provision of various job information to participate as members of society.

Fourth, programs that take into account the level of participation in cultural activities and national and racial considerations should be developed. This is because there are restrictions on cultural activities of migrant women depending on their educational background and nationality.

Fifth, TV broadcasting programs such as dramas, reality shows and entertainment that promote digital cultural life and social network services such as smartphones and tablets should be activated.

Finally, it is to provide economic support so that various methods can be implemented so far so that they can be adapted to the new society through active cultural activities. According to Park Eun-Mi et al., these policy support and various programs can improve the individual cultural adaptation and satisfaction with life among migrant women, thus, they will be able to adapt more flexibly to Korean culture and play a social role[16].

Furthermore, this study has some limitations. First, it was difficult to secure representativeness due 
to the small number of samples of the research subjects due to spatial constraints, as the survey was face-to-face under the social distancing situation.

Second, it was conducted on a number of migrant women with a certain degree of educational background and economic stability because the samples were examined by visiting the Multicultural Support Center.

Third, since the survey was conducted on multinational foreigners, the understanding of the questionnaire written in Korean may be conveyed differently from the researchers' intention. We would like to continue to pursue further research to overcome these limitations of the research.

\section{References}

[1] Cheol-hyun Bae, The great journey of man, 21st Century Books, korea, (2017), p.412.

[2] Eui-yong Chae, 'The Study on the Differences between Leisure Activities and Leisure Constraints in the Cultural Adaptation of Married Migrant Women', Sejong University Graduate School, Master's thesis, (2011), p.28.

[3] Okhee Jeong, Onjeong Chang, Seunghoon Hyun, Sunhee Lee, An Hyunjee, A Study on Developing and Pilot Operation of Family Leisure Program for Kumdarak Saturday Cultural Schools, Korea Culture and Arts Education Promotion Agency, (2019)

[4] Chun-yang Li, Sumin Kim, Hyunju Lee, Exploring Migrant Women's Experiences in Cultural Art as a Leisure: Focused on the "H" Chinese Traditional Dance Team, Journal of Learner-centered Curriculum and Instruction, (2020), Vol.20, No.5, pp.1089-1113, DOI : 10.22251/jlcci.2020.20.5.1089

[5] Sook Hyun Kim, Marriage Immigrant Women's Performance, It's Significance and Practice-Focused on 'Mama', the Performance of Marriage Immigrant Women in Seongdong-gu, Journal of Korean Theatre Studies Association, (2017), Vol.1, No.62, p.35-67, DOI : 10.18396/ktsa.2017.1.62.002

[6] https://news.joins.com/article/23728090, Mar 03 (2020)

[7] http://digitalchosun.dizzo.com/site/data/html_dir/2020/09/16/2020091680027, Sep 16 (2020)

[8] Yong-hwan Lee, Chung-hoon Park, Post Corona 19 Local administration and finance, How should I prepare?, Gyeonggi Research Institute, (2020), pp.418.

[9] Mi Young Jang, Intermediality of Novel and Mediacontents - Focused on the Korean novel after 2000, Korean Language and Literature, (2012), Vol.52, pp.225-226.

[10] Noe Chan-Sook, Transition to Post Digital Culture Era and Its Communication, A Treatise on The Plastic Media, (2016), Vol.19, No.2, pp.47-54, UCI : G704-001766.2016.19.2.022

[11] Kim Young Lan, Kiwon Hong, Kyung Ock Chun, Multicultural Arts Program as a Tool for Social Integration, The Journal of Multicultural Society, (2013), Vol.6, No.1, pp.81-107, DOI : 10.15685/jms.2013.02.6.1.81

[12] Immigration and Foreign Policy Statistics Monthly, Korea Immigration Service, February (2020)

[13] Il-soo Heo, The Effect of Multicultural Families' TV Entertainment Program on Multicultural Susceptibility of Runaway Youth, Multicultural Children and Youth Research, (2019), Vol.4, No.1, pp.107-134.

[14] https://newsis.com/view/?id=NISX20200904_0001155050\&cID=10201\&pID=10200, Sep 04 (2020)

[15] Bong-chan Ko, 'Exploring Research on Women's Leisure Pharmaceuticals in Korea's Marriage Migrant, Korean Tourism Association, pp.13, October, (2010), Korea

[16] Eun-mi Park, Kon-soo Lee, Multicultural Society and Adoption to Local Society, Korean Public Administration Quarterly, (2009), Vol.21, No.2, pp.407-429, UCI : G704-000253.2009.21.2.012 